\title{
Senam Menuju Lansia Sehat dan Bugar
}

\author{
Margareta Haiti' ${ }^{1}$, Novita Anggraini' ${ }^{2}$, Aprida Manurung ${ }^{3}$ \\ Fakultas Ilmu Kesehatan UNIKA Musi Charitas Palembang \\ Email :1margarethahaiti@ukmc.ac.id, 2novitaanggraini@ukmc.ac.id, \\ 3aprida@ukmc.ac.id
}

\begin{abstract}
Old age is a natural process experienced by both men and women who have reached the age of 60 years and over. Aging means that you have experienced a process of decline both physically and mentally. The elderly can still be productive when they have a healthy and fit body. Health can be maintained through a balanced nutritional intake and through physical activities such as gymnastics. Efforts to prevent disease in the elderly can be carried out through health checks. As for the purpose of this activity, the elderly are expected to be able to live healthy and fit to carry out their daily life. Methods: carry out elderly exercise together followed by health education and blood pressure checks for elderly mothers and fathers at the Sumarah Sukomoro Nursing Home, totaling 31 people. The results of blood pressure measurement showed that 33.3\% had pre-hypertension (BP 120-139mmHg), $20 \%$ had grade 1 hypertension (140-159 $\mathrm{mmHg})$, and $13.3 \%$ had grade 2 hypertension ( $\geq 160 \mathrm{mmHg}$ ).
\end{abstract}

Keywords: Elderly gymnastics, health chhecks

\section{Pendahuluan}

Dep Kes RI menyatakan Lanjut usia adalah proses alami yang terjadi pada individu laki-laki dan perempuan berusia 60 tahun ke atas. ${ }^{1}$ Lanjut usia (lansia) saat ini semakin meningkat sejalan dengan kemajuan ilmu pengetahuan dan teknologi (IPTEK) terutama di bidang kesehatan terutama di bidang kedokteran yang mampu menyembuhkan berbagai penyakit, perbaikan gizi dan sanitasi, menurunkan angka kematian pada bayi dan anak, meningkatkan kualitas umur harapan hidup. Salah satu dampaknya penduduk uisa lanjut usia bertambah banyak bahkan ada kecenderungan meningkat dengan pesat.

${ }^{1}$ Riri R, Moh.Rizki dan Cice T, 2019. 
Lanjut usia yaitu seseorang dengan usia 60 tahun ke atas. Menjadi tua bukanlah penyakit tapi merupakan proses yang mengakibatkan perubahan, proses menurunnya daya tahan tubuh dalam menghadapi rangsangan dari dalam dan luar tubuh. ${ }^{2}$ Proses menua atau lanjut usia merupakan sesuatu yang fisiologis dengan bertambahnya umur seseorang. Pada Lanjut usia, adanya kemunduran biologis yaitu mengendurnya kulit, keriput, rambut beruban, gigi mulai tanggal, pendengaran serta penglihatan berkurang, mudah lelah, gerakan menjadi lamban, dan kurang lincah.

Kemunduran lain yang terjadi pada lanut usia yaitu menurunnya kemampuan kognitif misalnya sering lupa, kemunduran orientasi (waktu, ruang, dan tempat). ${ }^{3}$ Seiring bertambahnya usia seseorang secara anatomi dan fisiologi tubuh mengalami berbagai kemunduran yang sering menimbulkan permasalahan dalam kesehatan tubuh lansia. Untuk mencegah munculnya permasalahan dalam kesehatan lansia biasakan melakukan: aktivitas fisik misalnya berjalan, mencuci, menyapu dan sebagainya Latihan fisik seperti senam, berjalan, berenang, dan lain-lain sekurangnya-kurangnya 30 menit sehari dalam 3 kali seminggu. ${ }^{4}$

Fisiologisnya, gerakan senam pada lanjut usia termasuk bagian tungkai, lengan, dan batang tubuh yang meningkatkan kontraksi otot yang berefek pada peningkatan kekuatan otot sehingga membantu dalam mempertahankan keseimbangan tubuh. ${ }^{5}$ Menurut Depkes, 1995 Senam lanjut usia memiliki dampak positif yaitu terjadinya peningkatan fungsi organ tubuh dan juga berpengaruh dalam meningkatkan imunitas dalam tubuh manusia setelah latihan teratur. ${ }^{6}$

Latihan fisik penting lanjut usia untuk meningkatkan kualitas hidup. Latihan yang teratur bisa meningkatkan hubungan sosial, meningkatkan

\footnotetext{
2 Kemenkes RI, 2016

${ }^{3}$ Maryam, 2012

${ }^{4}$ Kemenkes RI, 2016

5 Manangkot MV, Sukawana IW, Witarsa IMS, 2016

${ }^{6}$ Setyoadi, Yulian Wiji Utami, Sheylla Septina M.
} 
kesehatan fisik dan kesehatan mental. Latihan juga berperan penting dalam mengurangi risiko penyakit dan memelihara fungsi tubuh lansia. ${ }^{7}$

Olahraga atau senam banyak manfaatnya bagi kesehatan terutama pada lansia. Senam pada lansia lebih banyak manfaatnya daripada pada kaum muda. Senam lansia bisa menjadikan lansia bugar secara fisik sehingga bisa menjalani kehidupan sehari-hari dengan lebih mudah. ${ }^{8}$

\section{Metode}

Pada kegiatan pengabdian kepada masyarakat ini dilaksanakan di Panti Werdha Sumarah, dimana panti merupakan tempat tinggal bapak dan ibu usia lanjut yang sangat memerlukan pelayanan kesehatan seperti pemeriksaan tekanan darah serta melakukan kegiatan fisik yang menyenangkan seperti senam lansia. Kegiatan ini diharapkan dapat mencegah berbagai penyakit degenratif sehingga solusi yang ditawarkan adalah pemeriksaan tekanan darah dan senam lansia dan diharapkan lansia mulai menata hidupnya melaksanakan senam lansia setiap hari selama 30 menit. Tahapan kegiatan pengabdian kepada masyarakat yaitu sebagai berikut:

1) Pembentukkan tim PKM

2) Pembuatan proposal dan penyusunan anggaran pelaksanaan kegiatan pemeriksaan kesehatan dan senam lansia di Panti Werdha Sumarah Sukomoro

3) Perizinan kegiatan PKM

4) Rapat koordinasi

5) Persiapan pelaksanaan kegiatan pemeriksaan kesehatan dan senam lansia di Panti Werdha Sumarah Sukomoro

6) Melaksanakan kegiatan

7) Menyusun laporan kegiatan Pengabdian Kepada Masyarakat

${ }^{7}$ Ko \& Lee, 2012 dalam Stefanus M.K, Junaiti S, Henny Permatasari.

8 Indhryani R, 2020 


\section{Hasil dan Diskusi}

\section{Hasil}

Kegiatan Pengabdian Kepada Masyarakat (PKM) dalam bentuk senam lansia dan pemeriksaan tekanan darah yang dilaksanakan pada tanggal 19 Februari 2021 dihadiri 31 lansia yang tinggal di Panti Werdha Sumarah Sukomoro. Persentase peserta yang hadir pada kegiatan PKM ini, seperti tampak pada tabel berikut:

Tabel 1.1 Jumlah dan Persentase berdasarkan Jenis Kelamin

\begin{tabular}{|c|c|c|c|}
\hline No. & Kelas & Jumlah & Persentase \\
\hline 1. & Laki Laki & 15 & 48,40 \\
\hline 2. & Perempuan & 16 & 51,60 \\
\hline
\end{tabular}

\section{Sumber: Data di lapangan, 2021}

Tabel 1.2 Hasil Pemeriksaan Tekanan Darah

\begin{tabular}{|c|c|c|c|}
\hline No. & Nama & Umur (Thn) & Tekanan Darah \\
\hline 1. & $\mathrm{HJ}$ & 72 & $134 / 90$ \\
\hline 2. & CL & 80 & $133 / 110$ \\
\hline 3. & SS & 78 & $163 / 105$ \\
\hline 4. & $\mathrm{Yk}$ & 73 & $174 / 89$ \\
\hline 5. & $\mathrm{Yt}$ & 58 & $102 / 78$ \\
\hline 6. & An & 79 & $157 / 86$ \\
\hline 7. & $\mathrm{Ht}$ & 87 & $141 / 80$ \\
\hline 8. & Yhd & 69 & $175 / 102$ \\
\hline 9. & $\mathrm{Mn}$ & 64 & $147 / 81$ \\
\hline 10. & $\mathrm{Mr}$ & 79 & $133 / 77$ \\
\hline 11. & TA & 73 & $131 / 80$ \\
\hline 12. & $\mathrm{Fn}$ & 74 & $165 / 74$ \\
\hline 13. & Anl & 62 & $152 / 86$ \\
\hline 14. & $\mathrm{Ya}$ & 69 & $90 / 61$ \\
\hline 15. & I S & 70 & $124 / 71$ \\
\hline 16. & Ls & 83 & $113 / 83$ \\
\hline 17. & $\mathrm{Cr}$ & 98 & $156 / 75$ \\
\hline 18. & Ysf & 65 & $200 / 105$ \\
\hline 19. & Mld & 49 & $125 / 61$ \\
\hline 20. & $\mathrm{Hp}$ & 95 & $164 / 92$ \\
\hline 21. & Yhn & 60 & $120 / 90$ \\
\hline 22. & Ayg & 49 & $145 / 96$ \\
\hline 23. & Kn & 63 & - \\
\hline
\end{tabular}




\begin{tabular}{|c|c|c|c|}
\hline No. & Nama & Umur (Thn) & Tekanan Darah \\
\hline 24. & Wnt & 42 & $114 / 70$ \\
\hline 25. & $\mathrm{Nl}$ & 45 & $115 / 70$ \\
\hline 26. & $\mathrm{St}$ & 46 & $130 / 83$ \\
\hline 27. & $\mathrm{Iw}$ & 23 & $105 / 75$ \\
\hline 28. & $\mathrm{Mrt}$ & 37 & $131 / 81$ \\
\hline 29. & $\mathrm{Sht}$ & 80 & $160 / 95$ \\
\hline 30. & $\mathrm{R}$ & 40 & $135 / 94$ \\
\hline 31. & $\mathrm{Ngs}$ & 46 & $110 / 81$ \\
\hline
\end{tabular}

Sumber: Data di lapangan, 2021

Tabel 1.3 Daftar Berdasarkan Klasifikasi Hypertensi

\begin{tabular}{|c|c|c|c|c|c|c|}
\hline Kategori & $\begin{array}{c}\text { TDS } \\
(\mathrm{mmHg})\end{array}$ & Jumlah & $\%$ & $\begin{array}{c}\text { TDD } \\
\text { (mmHg) }\end{array}$ & Jumlah & $\%$ \\
\hline Normal & $<120$ & 7 & 23,3 & $<80$ & 10 & 33,3 \\
\hline Pra-hipertensi & $120-139$ & 10 & 33,3 & $80-89$ & 10 & 33.3 \\
\hline $\begin{array}{l}\text { Hipertensi } \\
\text { tingkat } 1\end{array}$ & $140-159$ & 6 & 20 & $90-99$ & 6 & 20 \\
\hline \multirow{2}{*}{$\begin{array}{l}\text { Hipertensi } \\
\text { tingkat } 2\end{array}$} & $>160$ & 7 & 23,3 & $>100$ & 4 & 13,3 \\
\hline & \multicolumn{4}{|c|}{$\begin{array}{l}\text { Hipertensi Sistolik Terisolasi } \\
140 \text { dan }<90\end{array}$} & 6 & 20 \\
\hline
\end{tabular}

\section{Sumber: Data di lapangan, 2021}

\section{Diskusi}

Berdasarkan hasil kegiatan PKM yang kami lakukan dari 31 peserta yang mengikuti senam dan pemeriksaan tekanan darah. Dari 31 lansia, 15 laki-laki dan 16 perempuan. Pada kegiatan PKM menunjukkan hasil pengukuran tekanan darah 33,3 \% yang mengalami prahipertensi (TD 120139mmHg), 20\% yang mengalami hipertensi tingkat 1 (140-159 mmHg), dan $13,3 \%$ yang mengalami hipertensi tingkat 2 ( $\geq 160 \mathrm{mmHg}$ ).

Proses menua adalah proses alamia tiga tahap kehidupan yaitu masa anak, dewasa, dan masa tua yang tidak dapat dihindari pada masing-masing 
individu. Bertambahnya usia mengakibatkan perubahan struktur dan fisiologis berbagai sel, jaringan, organ dan sistem pada manusia.

Pada proses penuaan, tubuh akan mengalami berbagai masalah penyakit kesehatan, misalnya hipertensi. Hipertensi atau yang biasa disebut tekanan darah tinggi, yaitu tekanan sistolik lebih dari $140 \mathrm{mmHg}$ dan tekanan darah diastolik lebih dari 90 mmHg. Hipertensi adalah suatu penyakit yang muncul karena interaksi dengan berbagai faktor. meningkatnya usia menyebabkan berbagai perubahan fisiologis. Pada lanjut usia terjadi peningkatan resistensi perifer dan aktivitas simpatik. Tekanan darah akan meningkat mulai pada usia 45-55 tahun dimana dinding arteri akan mengalami penebalan akibat penumpukan zat kolagen pada lapisan otot sehingga pembuluh darah akan berangsur-angsur menyempit.

Cara mencegah dan mengontrol risiko terjadinya hipertensi yaitu dengan cara berolahraga secara teratur. Pada beberapa studi yang telah dilakukan, bahwa terapi tanpa obat atau non-farmakoterapi dan obat atau farmakoterapi tidak hanya menurunkan tekanan darah akan tetapi juga bias menurunkan resiko stroke dan penyakit jantung iskemik. Terapi pemberian obat dengan diberikannya obat anti hipertensi, namun untuk terapi tanpa obat dilakukan dengan olahraga secara teratur. Olahraga yang dapat bias dilakukan lansia salah satunya yaitu olahraga senam lansia.

Menurut penelitian, senam merupakan serangkaian gerakan nada yang teratur, terarah, dan terencana yang dilakukan secara sendiri atau berkelompok dengan tujuan meningkatkan kemampuan fungsional raga. Menurut Suroto (2004) senam lanjut usia adalah olahraga ringan yang mudah dilakukan, serta dapat diterapkan pada lanjut usia. Senam lanjut usia bisa membantu tubuh supaya tetap bugar dan tetap segar sebab melatih tulang tetap kuat dan mendorong jantung bekerja optimal serta membantu menghilangkan radikal bebas yang berlebihan didalam tubuh lansia. 


\section{Simpulan}

Senam dan pemeriksaan tekanan darah merupakan hal yang penting untuk dilakukan terutama pada lansia, dimana terjadi perubahan secara fisiologis. Berdasarkan hasil survey pada lansia di Panti Sumarah, dari 31 lansia hanya 33,3 \% tekanan darah lansia yang normal, selebihnya sudah cenderung mengalami hipertensi. Hal ini dapat disimpulkan bahwa kesadaran terhadap pentingnya pemeriksaan darah pada lansia masih perlu pendampingan untuk perubahan pola hidup yang sehat dan pemeriksaan darah secara berkala dan melakukan senam. Senam lanjut usia adalah olahraga ringan dan sangat mudah dilakukan. Senam pada lanjut usia membantu supaya tubuh tetap bugar dan tetap segar. Senam pada lanjut usia untuk melatih tulang tetap kuat dan mendorong jantung bekerja optimal serta membantu menghilangkan radikal bebas yang berlebihan di dalam tubuh lansia.

\section{Daftar Referensi}

Dorland WA. Newman. Kamus Kedokteran Dorland. Edisi ke-29. Jakarta: EGC: 2000.

Indhryani R, 2020. Rekomendasi Senam Lansia, Rahasia Tetap Bugar di Usia Senja. Artikel Kesehatan

Kemenkes RI, 2016, Keperawatan Gerontik, Jakarta

Kemenkes RI, 2016, Buku Kesehatan Lansia, Jakarta

Kementerian Kesehatan RI , Infodatin, 2016, Pusat Data dan Informasi

Maryam. S. dkk, 2012. Mengenal Usia Lanjut dan Keperawatannya. Jakarta: Salemba Medika

Meril Valentine Manangkot, I Wayan Sukawana, I Made Surata Witarsa, 2016, Pengaruh Senam Lansia Terhadap Keseimbangan Tubuh Pada Lansia Di Lingkungan Dajan Bingin Sading, Jurnal Keperawatan COPING NERS Edisi Januari-April 2016

Riri R, Moh.Rizki dan Cice T, 2019, Pengaruh Senam Lansia terhadap Tigkat Kebugaran Fisik pada Lansia berdasar atas Uji Jalan 6 Menit, Jurnal Integrasi Kesehatan \& Sains, Vol. 1 No. 2 Tahun 2019

Sari RP, Kamil EN, 2017. Pengaruh Senam Lansia Terhadap Tekanan Darah Pada Landsia Hipertensi di Puskesmas Walantaka. JurnalIlmiah Kesehatan. 
Setyoadi, Yulian Wiji Utami, Sheylla Septina M. Senam Dapat Meningkatkan Keseimbangan Tubuh Lansia Di Yayasan Gerontologi Kecamatan Wajak Kabupaten Malang, Jurnal Ilmu Keperawatan, Volume 1, No. 1, Mei 2013

Stefanus M.K, Junaiti S, Henny Permatasari, Peningkatan Kualitas Hidup Lanjut Usia (Lansia) Di Kota Depok Dengan Latihan Keseimbangan, Jurnal keperawatan, Volume 21 No.2, Juli 2018, hal 109-116 